\title{
Lessons from analysing mortality from six major flood events in France $(1930-2010)$
}

\author{
Martin Boudou ${ }^{1, a}$, Michel Lang ${ }^{1}$, Freddy Vinet ${ }^{2}$, Denis Coeur ${ }^{3}$ \\ ${ }^{1}$ Irstea, Hydrology-Hydraulics research unit, Villeurbanne, France \\ ${ }^{2}$ University Paul Valery Montpellier 3, Montpellier, France \\ ${ }^{3}$ Acthys-Diffusion, Biviers, France
}

\begin{abstract}
Evolution of flood mortality is complex as several opposite factors come into play. On one side, flood risk has been aggravated due to an increase of the number of inhabitants within the area at risk, and to an increasing of simple-storey houses without safe area. On the other side, flood risk is better managed due to a better efficiency of warning offices and civil protection actors. It is intended to demonstrate the potential of historical information on past flood events to give a better understanding of the main factors leading to mortality during flood events. This paper focuses on a set of six fatal floods from 1930 to 2010 in France, with a variable number of fatalities (from 25 to 423 ). Information was gathered on the main characteristics of past flood mortality: number of fatalities, death location, date and time of death, death circumstances, age and gender of victims. Based on the six flood events, the paper shows contrasted patterns on flood mortality in terms of spatial distribution, death location (inside/outside buildings), age of flood victims. The main factors leading to flood mortality are considered, such as population exposed to violent and sudden flooding, vulnerable built environment, inadequate behaviour of individuals and warning failures.
\end{abstract}

\section{Introduction}

Between 1998 and 2009, floods in Europe have caused some 1126 deaths, the displacement of about half a million people and at least EUR 52 billion in insured economic losses [1]. Catastrophic floods endanger lives and cause human tragedy as well as heavy economic losses. Even if the annual death of rate from flood is low in comparison with anthropogenic sources (e.g. in France: about 10 flood deaths to compare with 60000 , 30000 and 3400 deaths by tobacco, alcohol or road accident), catastrophic floods have large social impacts as the fatalities happen simultaneously or during the same days, on a restricted geographic area.

Coastal populations can be seriously impacted by extreme sea levels caused by a storm (e.g. loss of 1800 lives in Netherland on 31 January - 1 February 1953 [2]; 1100 deaths after Hurricane Katrina in the state of Louisiana USA on 29 August 2005 [3]). Inland population can also be exposed to sudden flooding after flash floods, storms, dyke breaching or dam breaking. Table 1 gives the list of the seven most catastrophic flood events since 1850 with more than 100 fatalities in France [4]. Even if some uncertainties remain on the exact identification of victims, especially during the previous centuries, it clearly shows that extreme flood mortality has been reduced as the deadliest disasters are all prior to 1960. It could be relied to significant progress in warning and rescuing operations. But such positive effects can be counterbalanced by the increase of the number of

a Corresponding author: michel.lang@irstea.fr inhabitants within the area at risk, and by inadequate people vulnerability or behaviour.

\begin{tabular}{|c|c|c|}
\hline Flood event & Flood type & Deaths \\
\hline $\begin{array}{c}\text { Sept. 1928 } \\
\text { Guadeloupe Island }\end{array}$ & Cyclone & 1200 \\
\hline June 1875, Garonne basin & Flash flood & 500 \\
\hline $\begin{array}{c}\text { December 1959 } \\
\text { Malpasset dam }\end{array}$ & Dam breaking & 423 \\
\hline $\begin{array}{c}\text { March 1930 } \\
\text { Tarn \& Garonne basins }\end{array}$ & Flash flood & 230 \\
\hline $\begin{array}{c}\text { July 1892 } \\
\text { Saint-Gervais }\end{array}$ & $\begin{array}{c}\text { Glacier- } \\
\text { outburst flood }\end{array}$ & 175 \\
\hline $\begin{array}{c}\text { January 1948 } \\
\text { Réunion Island } \\
\text { Sept. 1875 } \\
\text { Orb \& Vernazobre basins }\end{array}$ & Cyclone & 165 \\
\hline
\end{tabular}

Table 1. Catastrophic floods since 1850 with more than 100 deaths in France

This paper intends to demonstrate the potential of historical information on past flood events to give a better understanding of the main factors leading to mortality during flood events. We present on section 2 the main characteristics on a set of six fatal floods from 1930 to 2010 in France, with variable flood casualty figures. The main factors leading to flood mortality are considered in section 3, such as population exposed to violent and 
sudden flooding, vulnerable built environment, inadequate behaviour of individuals, and warning failures. A conclusion gives some key issues for a reduction of flood mortality.

\section{Six fatal flood events in France (1930- 2010)}

In 2011, during the French Preliminary Flood Risk Assessment of the Floods Directive, a set of 176 flood events has been selected from the period 1770-2011 by the French Ministry of Ecology (MEDDE). A sample of six fatal floods events was selected from this data set: March 1930, October 1940, December 1959, January 1980, November 1999 and February 2010 (table 2). Such events have been selected based on several criteria: high mortality, strong social and political impacts, and good variability in terms of period of occurrence, location and flood type. We have three "modern" events (in 1980, 1999 and 2010) which can be considered as representative of the current flood risk conditions, and three "past" flood events (in 1930, 1940 and 1959).

\begin{tabular}{|c|c|c|}
\hline Flood event & Flood type & Deaths \\
\hline $\begin{array}{c}\text { March 1930 } \\
\text { Tarn \& Garonne basins }\end{array}$ & Flash flood & 230 \\
\hline $\begin{array}{c}\text { October 1940 } \\
\text { Tech \& Têt basins }\end{array}$ & Flash flood & 57 \\
\hline $\begin{array}{c}\text { December 1959 } \\
\text { Malpasset dam }\end{array}$ & Dam breaking & 423 \\
\hline $\begin{array}{c}\text { January 1980, Hyacinthe } \\
\text { Réunion Island }\end{array}$ & Cyclone & 25 \\
\hline $\begin{array}{c}\text { November 1999 } \\
\text { Aude basin }\end{array}$ & Flash flood & 35 \\
\hline $\begin{array}{c}\text { February 2010, Xynthia } \\
\text { French Atlantic coast }\end{array}$ & Storm & $47(*)$ \\
\hline
\end{tabular}

(*) including 41 deaths by flooding

Table 2. Six fatal flood events in France from 1930 to 2010

A short description of each flood event is presented here based on a series a monographs produced by [5].

\subsection{The March 1930 flood event}

From the 1st to the 5th March 1930, one of the most significant flood events of the 20th century occurred in France. Following a heavy Mediterranean rainfall event, severe floods affected a large part of South-West France and, more specifically, the Tarn and Garonne river catchments (cf. Fig. 1). The exceptional flood magnitude, with a return period estimated at more than 200 years for the lower Tarn River, led to many house collapses along the hydrographic network. Based on documentary sources, the event caused at least 230 fatalities, meaning that the March 1930 event was the second deadliest flood of the 20th century (after the Malpasset dam burst in 1959, with 423 deaths). The flood event was responsible for significant economic losses estimated at around EUR 600 million. The subsequent impacts can be regarded as exceptional. For example, a day of national mourning in memory of the fatalities was instituted for the first time in
France. Furthermore, a new risk policy was established, setting out a new framework for flood risk management at the national scale.

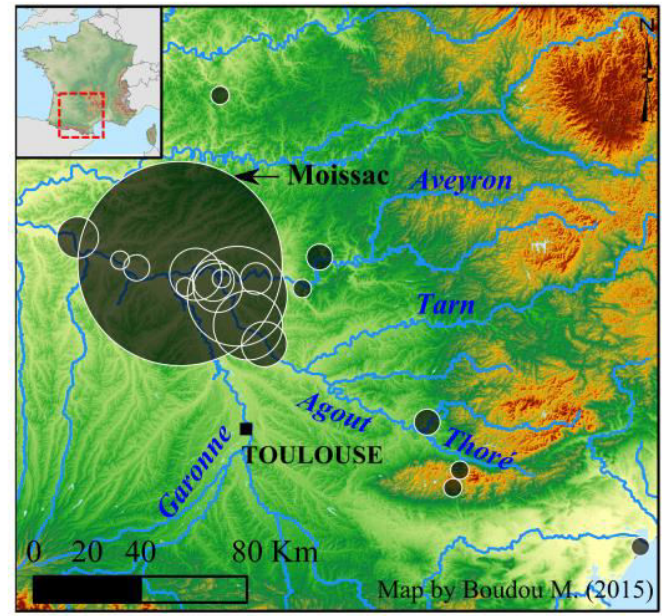

Legend

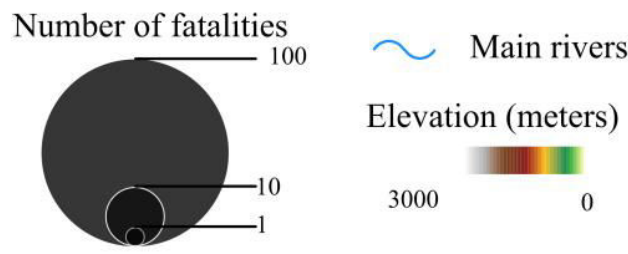

Figure 1. Flood fatalities during the March 1930 flood event

\subsection{The October 1940 flood event}

A major flood event affected Catalonia (i.e. the Eastern Pyrenees, both in Spain and in France) between the 16th and 21st October 1940. Its impacts in France were mainly concentrated along the Tech and Tet river valleys.

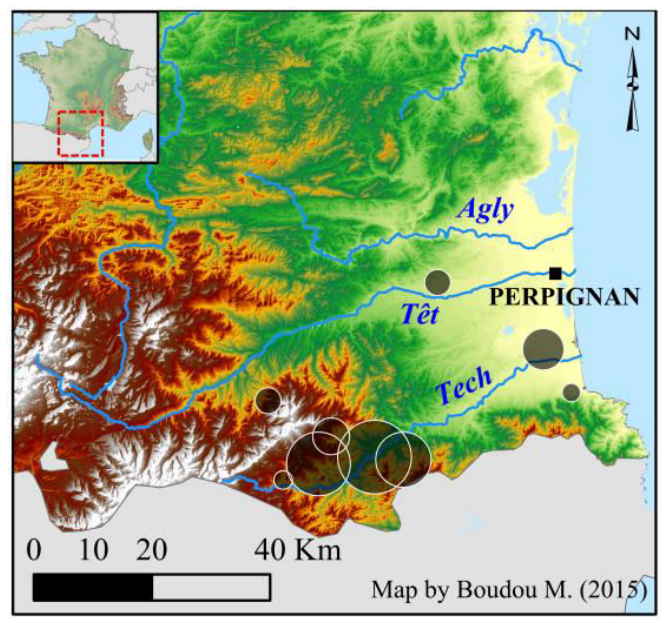

\section{Legend}

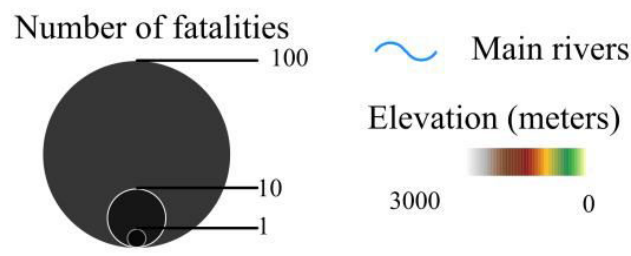

Figure 2. Flood fatalities during the October 1940 flood event 
According to the documentary sources collected, the flood event led to 57 deaths in France (Fig. 2) and 90 in Spain [6], generally resulting from house collapses [7]. Many municipalities from the Pyrenean valleys were strongly affected, in some cases with the complete destruction of villages such as the thermal resort of Amelie-les-Bains. The amount of damages is higher than EUR 1 billion. Because of its occurrence during the Second World War, and in spite of huge human and economic losses, this flood event led to few consequences at the national scale. Nevertheless, the October 1940 event remains the design flood for local management policies as well as one of the most significant hydro meteorological events ever recorded in France since the beginning of stream-gauging measurements.

\subsection{The breaking of Malpasset dam in December 1959}

The Malpasset dam was an arch dam, $60 \mathrm{~m}$ high and $220 \mathrm{~m}$ wide, located approximately $7 \mathrm{~km}$ north of Fréjus on the French Riviera, southern France, in the Var department (Fig. 3).

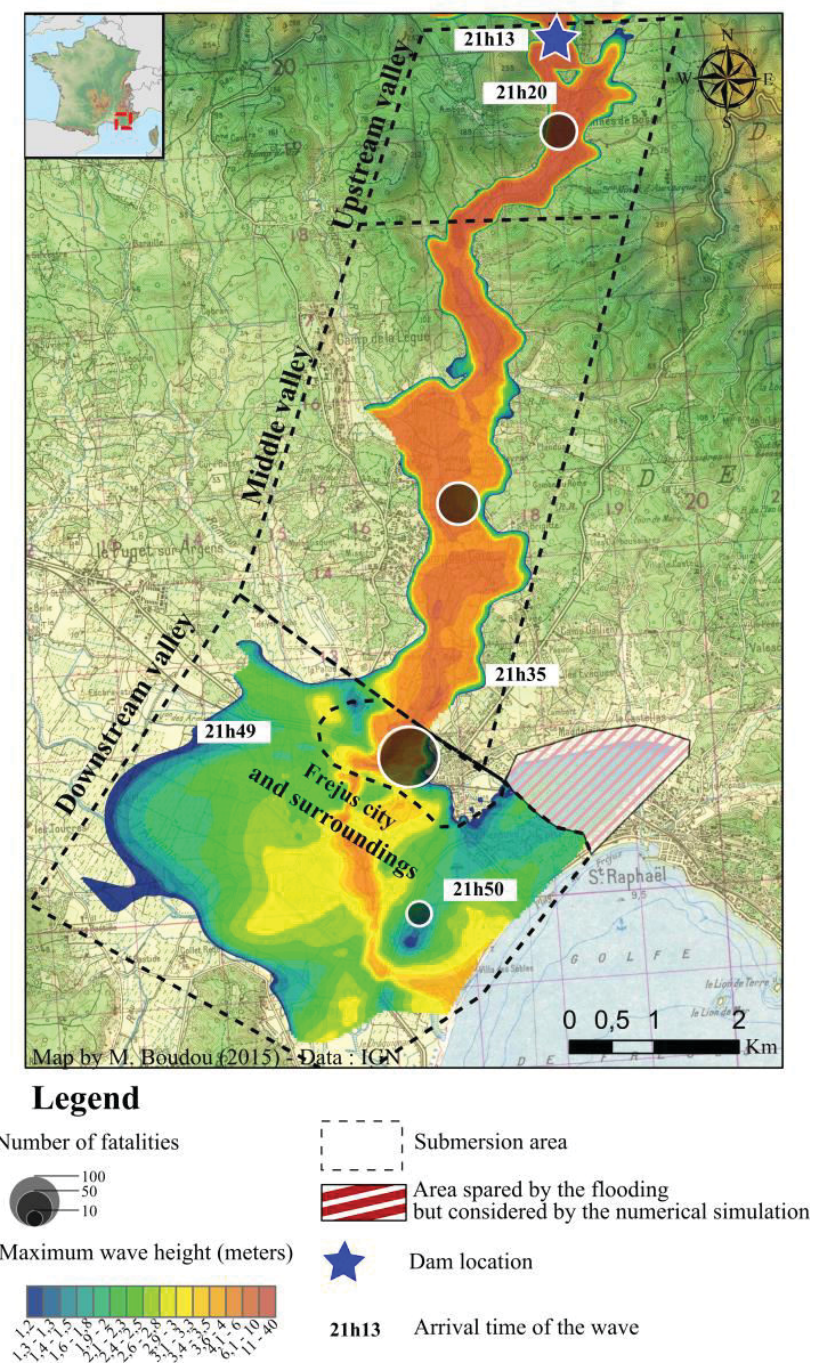

Figure 3. Flood fatalities during the breaking of Malpasset dam in December 1959
It collapsed at 21:13 on December 2, 1959, with a massive dam break wave, initially $40 \mathrm{~m}$ high and moving at $70 \mathrm{~km} / \mathrm{h}$, destroying two small villages, Malpasset and Bozon, and the highway construction site of MarseilleNice. It reached the city of Fréjus 20 minutes later, still standing $3 \mathrm{~m}$ high, and finally the sea at 22:00. The event caused 423 fatalities and the damage amounted to a total of EUR 110 million. The causes of the dam break are multiple. Firstly a strong pressure under the dam was not correctly accounted for, based on available knowledge on rock mechanics at the time. Some early signs of dam weakness may have been detected if the filling of the dam have been correctly monitored. Unfortunately, despite the dam construction was completed in October 1954, the reservoir was not yet filled 5 years later, due to a litigation procedure with a fluorspar mine. At the end of November, about $250 \mathrm{~mm}$ of rain in 6 days induced a rapid rise of the water within the reservoir without any detailed monitoring. Finally, the opening of the flood gates was postponed only 3 hours before the break, at 18:00, as the authorities firstly refused, claiming the highway construction site was in danger of flooding. This flood event remains the deadliest failure dam catastrophe in Europe after the Vajont catastrophe in Italy (October 1963, more than 2000 dead). It led to the creation of a National Committee on Dam Safety (CTPB) on 1966.

\subsection{The January 1980 Hyacinthe cyclone}

The January 1980 event is linked with the occurrence of cyclone Hyacinthe that affected Réunion Island in the Southern Indian Ocean over a period of two weeks from the 15th to the 28th January 1980.

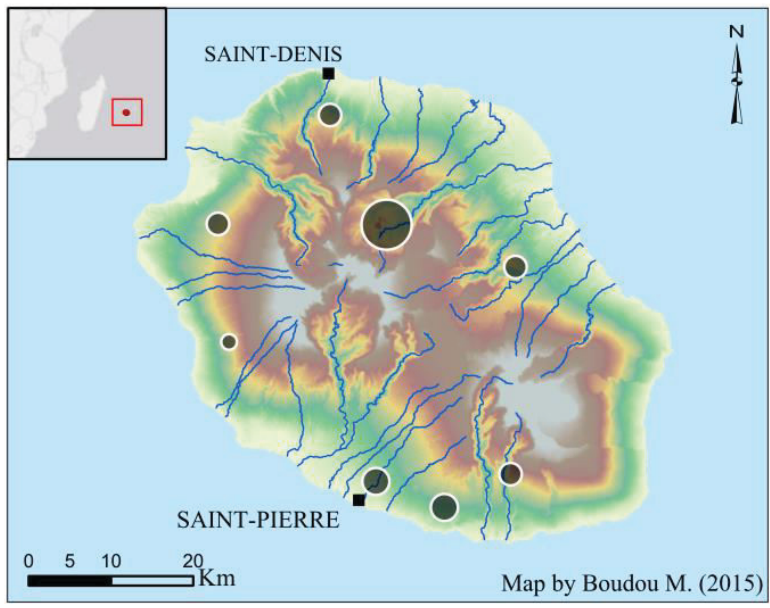

\section{Legend}

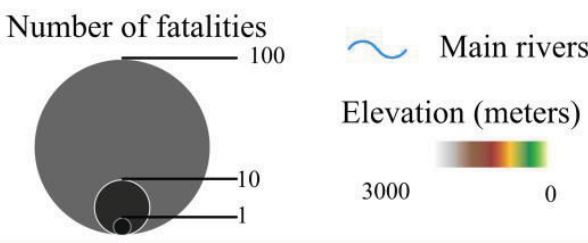

Figure 4. Flood fatalities during the January 1980 Hyacinthe cyclone 
The exceptional precipitation triggered by the cyclone (e.g. with $6083 \mathrm{~mm}$ over a 15 day period) generated significant and generalized floods all over the island, leading to a great amount of damage estimated at around EUR 300 million. A total of 25 fatalities were reported (Fig. 4), as well as extensive damage to road networks and buildings. Indeed, the January 1980 event remains a rainfall world record [8], and spurred the creation of a new risk containment policy for the rivers of Réunion Island.

\subsection{The November 1999 flood event}

From the 12th to the 13th of November 1999, a generalized flood event took place in the Languedoc region of the South of France (Fig. 5). The Aude River and its tributaries were strongly impacted by floods, with a return period estimated at around 100 years. Due to the heavy rainfall and high flow velocities, numerous villages, roads and railways were impacted. In total, 35 fatalities were registered [9], making this event the deadliest since September 1992 in France (41 deaths). Significant damage was recorded, with economic losses estimated at around EURO 770 million [10]. Owing to the reports of severe failures in the flood warning process, the November 1999 event partly contributed to the setting up of the national department of flood forecasting (SCHAPI) to improve the forecasting of flash floods resulting from heavy rainfall events [11].

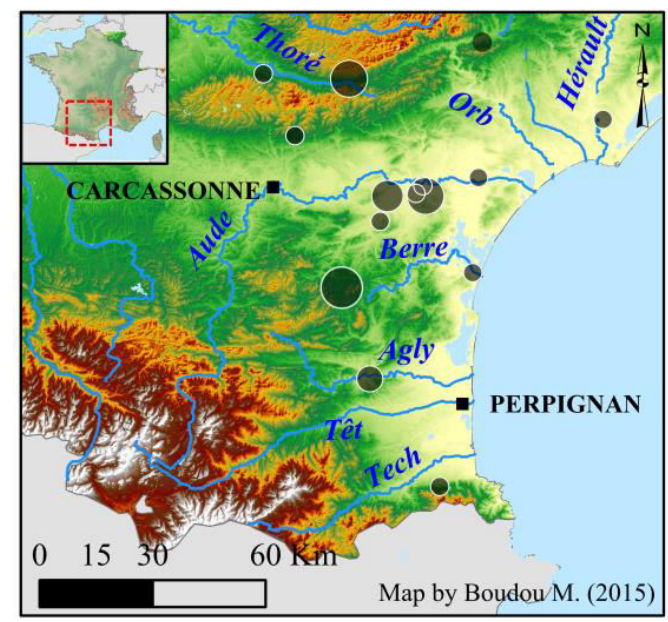

\section{Legend}

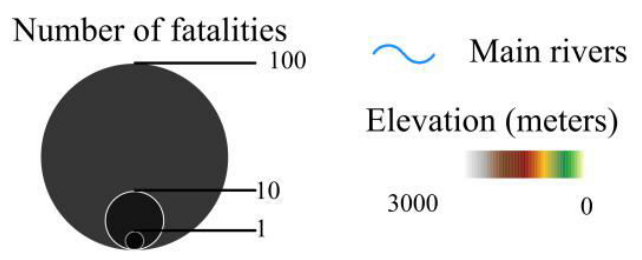

Figure 5. Flood fatalities during the November 1999 flood event

\subsection{The Februrary 2010 Xynthia storm}

From the 27th to the 28 th of February 2010, a violent storm crossed the French Atlantic coast with strong wind gust $(140 \mathrm{~km} / \mathrm{h})$. Some previous storms were more intensive (e.g. Martin storm on the 26 th of
December 1999, 198 km/h, Oléron Island; Klaus storm on the 23rd -25th of January 2009, $170 \mathrm{~km} / \mathrm{h}$, Atlantic coast). In fact, this coastal flooding was severe due to a combination of two factors [12]: a storm surge due to a 970 mbar low-pressure and strong wind, with a great equinox tide (coefficient 102 over 120). A total of 47 fatalities are reported (including 41 from submersions), especially on Vendée and on Charente-Maritime departments (Fig. 6). About $200 \mathrm{~km}$ of sea dikes have been damaged, as well as many infrastructures (road, bridges, railway...), buildings and economic activities (crop, shellfish aquaculture...). One million homes were left without power in western France. The total amount of damages is estimated at around EUR 2.5 billion. A national Rapid Inundation Plan was launched by the French Government in February 2011.

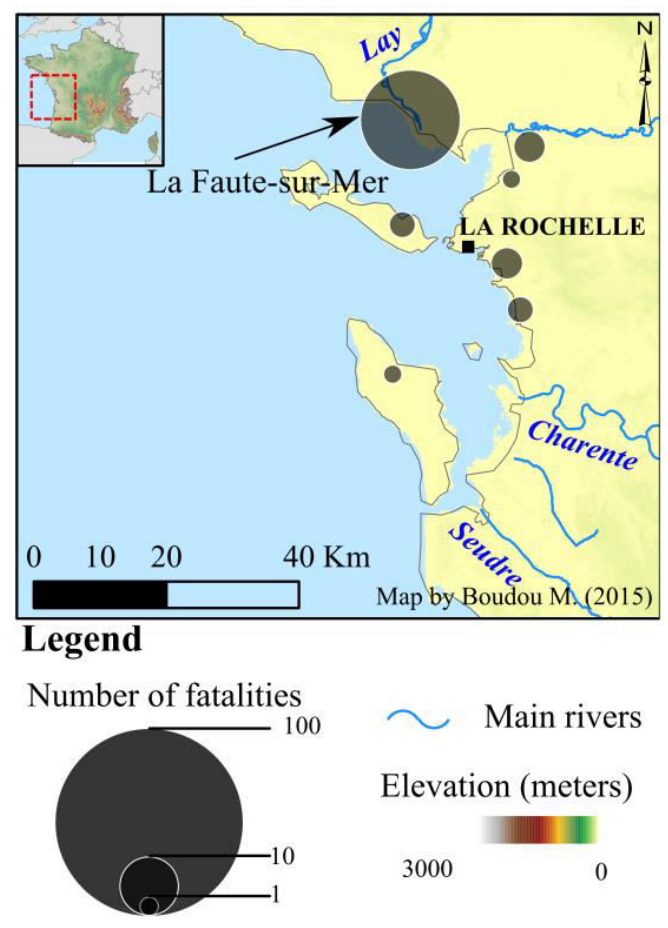

Figure 6. Flood fatalities during the February 2010 Xynthia storm

\section{Main factors leading to flood mortality}

As stated by [13] and [14], the number of fatalities resulting from a flood depends on many factors such as:

- Number of inhabitants in the area;

- Possibilities for preventive evacuation;

- Flood characteristics (depth, flow velocity, onset of flooding);

- Possibilities for fleeing or sheltering;

- Vulnerability and behaviour of the inhabitants and the environment.

The six flood events will provide good contrasted case studies on flood mortality. 


\subsection{Population exposed to violent and sudden flooding}

The three "past" flood events show a clear pattern of concentrated fatalities within an area where flood characteristics were extreme. During the March 1930 event, a set of unfavourable conditions $(700 \mathrm{~mm}$ of rain in 7 days + very wet winter with twice the climatic average values during the 5 preceding months + snow melting + coincidence of peak discharge between tributaries) led to an extreme flood on Agout and Tarn rivers. The return period of the peak discharge was significantly greater than 100 years, and led to the overflowing of dikes in the city of Moissac. According to figure 7 , the city centre was flooded suddenly following three branches on the railway embankment. This led to a high number of deaths (130) in the city centre of Moissac.

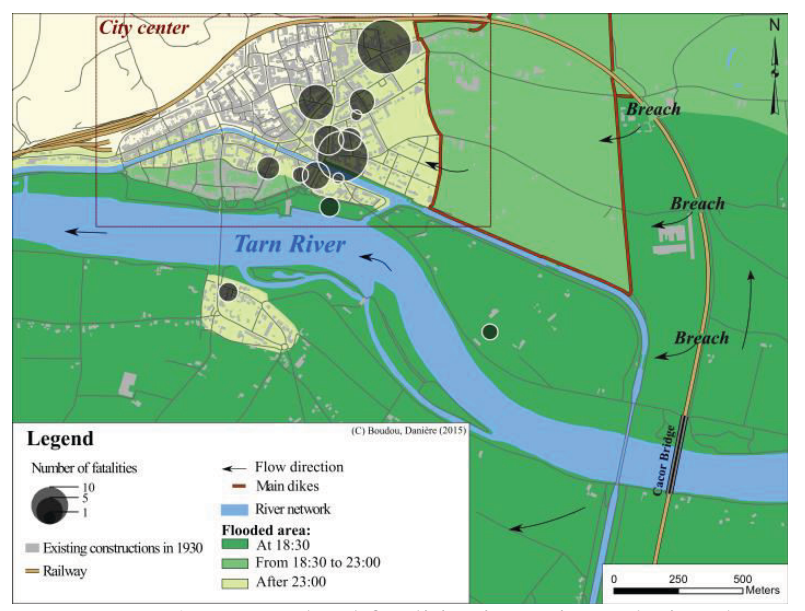

Figure 7. Flood fatalities in Moissac during the 3-4 March 1930 flood on Tarn river

The October 1940 flood event was concentrated on the Tech and Têt rivers (Fig. 2). Figure 8 gives the isohyet for $800 \mathrm{~mm}$ precipitation over a period of three days, the return period of the maximum peak discharge, and the fatalities recorded.

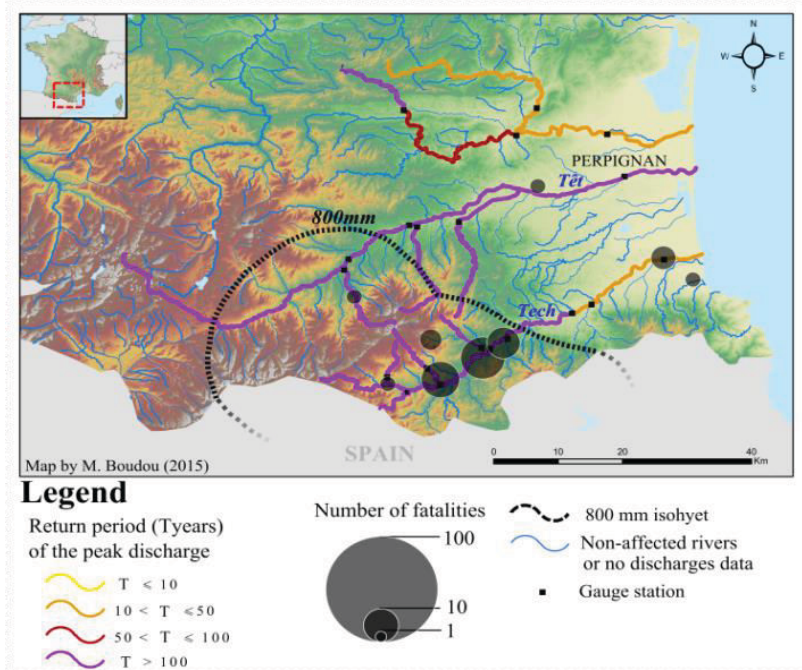

Figure 8. Cross-plot of flood fatalities versus return period of peak discharge and precipitation over $800 \mathrm{~mm}$ (17-20 October 1940)
The most impacted locations clearly correspond to cities within the $800 \mathrm{~mm}$ isohyet. These cities were mainly affected by flood return period higher than 100 years at the only exception of 5 deaths located on the downstream part of the Têt catchment (train accident).

On the 2nd of December 1959, the fatalities recorded during the Malpasset dam break were located within the area of the dam break (Fig. 3). As the wall of water was between $20 \mathrm{~m}$ to $3 \mathrm{~m}$ high (from area 1 to area 4), people had no chance to survive except to escape. People living in villages upstream and the workers of the highway construction site (area 1) were almost all killed (both highly damaged and taken by surprise), as the city of Frejus (area 3) was highly impacted due to a dense population.

The three "modern" events show a more contrasted pattern. As the January 1980 Hyacinthe cyclone (Fig. 4) and the November 1999 flood (Fig. 5) had a large spatial extent, the fatalities have been widely distributed. During the November 1999 event, the wide area of 48 hour rainfall larger than $300 \mathrm{~mm}$ (red and pink colours on Fig. 9) does correspond to a large number of deaths. Many deaths were resulting from people driving and being surprised by the high speed water rising in small catchment areas. A high mortality can also be observed in the low flood plains of the Aude River. As in Moissac in 1930, a dyke breaching can be pointed as one of the main cause of these fatalities.

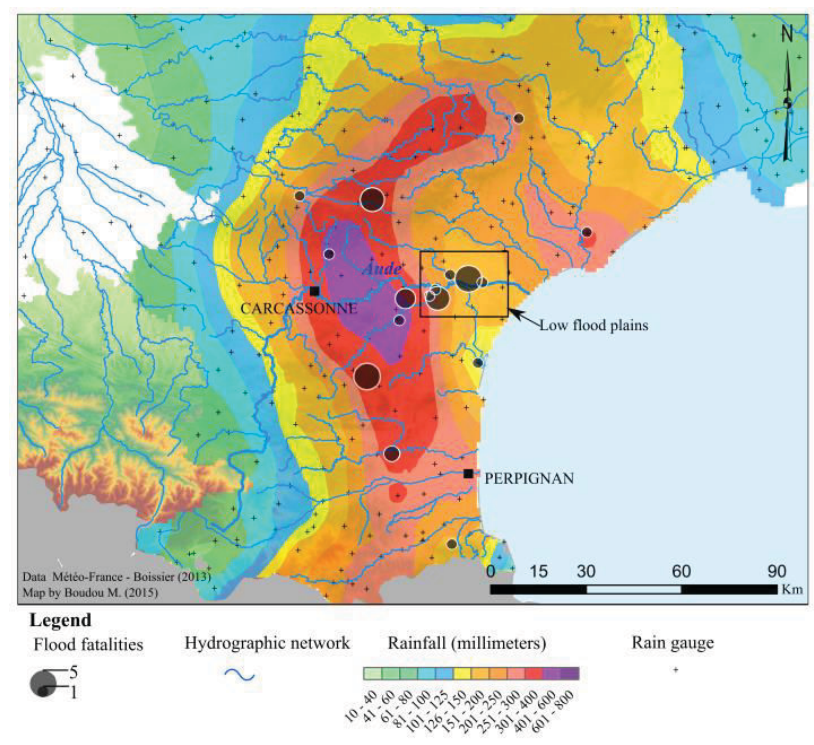

Figure 9. Fatalities and rainfall intensity $\left(11^{\text {th }}\right.$ to $13^{\text {rd }}$ November) during the November 1999 flood event

The death locations of the February 2010 flood event are focussed on the town of La-Faute-sur-Mer (Fig. 6). It relates to a poor policy of city planning, with new simplestorey houses just below coastal dikes. Most victims were living at a distance lower than $400 \mathrm{~m}$ from dikes [15].

\subsection{Vulnerable built environment}

A positive evolution of flood vulnerability is related to a better resilience of buildings to flooding. During past 
floods, many houses collapsed as the building materials were vulnerable to prolonged immersion. From 3 rd to 4 th March 1930, about 650 houses collapsed in Moissac, with 130 deaths. Figure 10 gives a typical picture of a devastated city located closed to Moissac, just after the March 1930 flood.

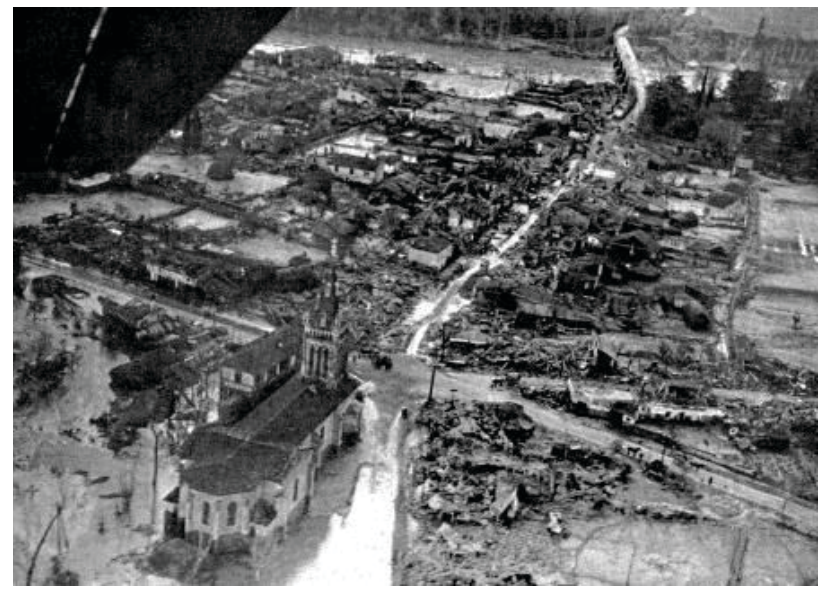

Figure 10. Village of Reyniès after the March 1930 flood (19 deaths) (La Dépêche, 03/05/1930)

At the opposite, a sensitive issue is the development of one-storey buildings, leading to higher human vulnerability due to the lack of a refuge floor. This was especially true during the Xynthia storm where about $85 \%$ of the victims were living on such buildings [5]. In addition, electric roller shutters were inoperative during the flood and prevented people from evacuating. In the town of La-Faute-sur-Mer, elderly population was the most impacted, as the median age of population was 52 years in 2010, to compare with the median age of victims (74 years) [15].

\subsection{Inadequate behaviour of certain individuals}

Historical accounts on the mortality during floods give evidence of inadequate behaviour of certain people. During the March 1930 flood, at least 4 fatalities are related to an individual rescue attempt of persons requiring assistance, with a tragic end of the volunteer. On the evening of the 17th of October 1940, the whole village of Bénat (upstream Arles-sur-Tech town) was advised of the danger of a possible break of a log jam by the electric factory of La Llau upstream. A temporal water reservoir $15 \mathrm{~m}$ high lasted about two hours before its failure. A farmer and his family died as they prefer to first rescue their animals [16]. Two similar fatalities are reported on two isolated houses downstream Arles-surTech. During the January 1980 Hyacinthe cyclone, at least 9 persons died as pedestrians, mainly by crossing a submersible road during flood or staying close to the flooding rivers. These fatalities generally concern men and people younger than 20 years old, confirming that this population is more disposed to risky behaviours [17]. During the November 1999 flood, about ten drivers did not comply with a driving ban on a submerged road and died.

\subsection{Warning failures}

It should be noted that each of the 6 flood events led to some missing or inadequate warnings. In comparison with the present situation, flood warning during the three "past" floods was either poor or absent. A flood warning was effective during the November 1930 and the October 1940 floods, but not totally during the week-end on the former, and during the night on the latter. Figure 11 shows clearly the difference between the hydrometric network on Tech, Têt and Agly catchments, in 1940 and today. It did not help to provide a good warning at the time. During the Malpasset dam breaking in December 1959, no warning system did exist. In 1968, a national French system of warning was set up in case of break of large dams, higher than $20 \mathrm{~m}$ or with more than $15 \mathrm{hm}^{3}$.

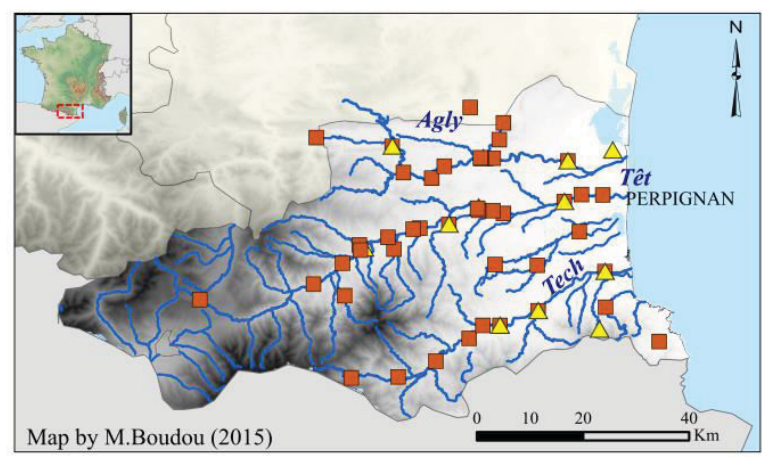

\section{Legend}

$$
\begin{aligned}
& \triangle \text { Gauge station (1940) } \frown \text { Hydrographic network } \\
& \text { Gauge station (2015) }
\end{aligned}
$$

Figure 11. Hydrometric network on Tech, Têt and Agly catchments, in 1940 and today

Structural reforms have been introduced after each of the three "modern" events. The January 1980 Hyacinthe cyclone was in fact very difficult to manage as the storm trajectory has been erratic. Hyacinthe changed six times its direction, and crossed the coasts of Réunion Island three times, triggering an exceptional rainfall event in terms of duration and intensity. At the time of the disaster, the warning system was related to the SaffirSimpson hurricane wind scale and was not adapted to intense rainfall. Today a specific warning system operates for extreme rainfall events on Réunion Island. During the November 1999 flood event, some miscommunication of the flood warning system has been noted during the week-end. It was concluded that the size of some warning offices was too small, with part-time forecasters. In 2003, the national department of flood forecasting (SCHAPI) was created and the former 52 Flood Warning departments were rearranged into 22 Flood Forecasting departments. Moreover, the meteorological forecasting of the Xynthia storm in February 2010 was really effective in terms of wind intensity and location. A red alert corresponding to the highest warning level has been correctly issued, but the warning message was not completely adequate. Even if information of possible coastal flooding was displayed, the main instructions 
were to remain in the buildings, taking shelter from the wind, and not eventually to move on a flood-proof location. The warning messages have been today adjusted, with a new "coastal flooding" type of alarm and the corresponding instructions.

\section{Key issues for a reduction of flood mortality}

The set of six fatal flood events in France (19302010) provided a series of contrasted patterns on flood mortality, which can be used for reducing the impact of future flood events. Some key issues on flood mortality are to: $1 /$ correctly assess the population exposed to violent and sudden flooding; 2 / reduce the vulnerability of buildings; 3 / improve the education and awareness of population; 4/ develop an efficient warning and disaster evacuation system.

Issue 1. The spatial analysis of flood mortality gives evidence that the standard approach of mapping both the flood hazard and the flood stakes gives a first insight of the flood risk. Special caution must be taken with regard to inhabited areas subject to sudden flooding from flash floods, dike breaching or dam break. Some high danger areas may therefore be detected. As an example, in response to the coastal flooding of Xynthia storm, the French Government decided to expropriate houses at risk, with a compensation based on the value of the real estate prior to the storm. A total of 1270 houses have been destroyed. Interaction between flood hazard and population at risk may also be studied by using a Life Safety Model [18]. It can help to study various scenarios of land use and evacuation systems.

It is also possible to cross the flooded area during a historical flood with the present land use. [19] did a comparison of the flood vulnerability of two French cities, Besançon and Moissac, which were largely impacted by floods in January 1910 and March 1930, respectively. In the former case, there has been no extension of the urban area within the old city of Besançon since 1910, and the flood vulnerability decreased as some previously residential areas are now used as administrative buildings. In the latter case, the changes in vulnerability show a more critical pattern, with a grown in spatial extent of Moissac since 1930.

Issue 2. Despite significant progress has been made for enhancing the water resistance of buildings (remind the recurring collapses of buildings during past flood events), some recent developments present problematic issues. The ground floor of some existing buildings has been modified for residential purpose, whereas it was previously related to storage purpose. At the opposite, new one-storey buildings have been constructed within a flood area, without any refuge floor. It is therefore important to conduct a vulnerability assessment of buildings and find the best solution: addition of a refuge floor, local protection, alarm system, expropriation...

Issue 3. It is really hard to achieve a comprehensive solution to inadequate behaviour during floods. Last year, for example, during a severe Mediterranean thunderstorm in the Cannes region on the $3^{\text {rd }}$ of October 2015, eight people died in Mandelieu-la-Napoule, by going down to an underground parking to rescue their car. A better awareness of population will require a wide variety of actions: recommendations of adapted behaviour during floods, memorial actions on past floods, dissemination of information about flood risk and recent flood events...

Issue 4. During the last decades, significant progress has been made on flood warning: meteorological models have been improved, density of hydrometric network is higher and dissemination of information is more effective. Civil protection services have a decisive role, as they are able to deploy rapid response teams. As an example, during the night of Saturday 27 to Sunday 28 February 2010, more than 2500 professional rescuers were able to have 37000 rescue operations and to assist 1500 persons [20]. It is important to have a systematic feedback regarding all serious flood events and to continue to improve the system, by having a good assessment of the exact location of flooded areas, reducing the false alerts, providing relevant information during the event, correctly managing the rescue operations... It is also important to improve prevention, by reducing the stakes and the vulnerability within the flood area. This will impact the number of inhabitants to be rescued in the event of floods.

\section{References}

1. European Environment Agency (2010). Mapping the impacts of natural hazards and technological accidents in Europe. An overview of the last decade. EEA Technical report No 13/2010, 146p.

2. Wolf J. and Flather R. A. (2005). Modelling Waves and Surges during the 1953 Storm. Phil. Trans. R. Soc. A, 363, 1359-1375.

3. Miller A., Jonkman S. N. and Van Ledden M. (2015). Risk to life due to flooding in postKatrina New Orleans. Nat. Hazards Earth Syst. Sci., 15, 59-73.

4. Lang M., Cœur D., Audouard A., VillanovaOliver M. Pène J.P. (2016). BDHI : a French national database on historical floods. Flood Risk 2016 Conference, 5p.

5. Boudou M. (2015). Approche multidisciplinaire pour la caractérisation d'inondations remarquables : enseignements tirés de neuf évènements en France (1910-2010). PhD, Irstea - Lyon, Univ. Montpellier III, 463 p. + 450 p. (appendix).

6. Llasat M.C. (2004). La vulnérabilité en Catalogne et la perception sociale. La Houille Blanche, 6, 71-75.

7. Battle M. and Gual R. (1981). 1940 L'Aiguat: les inondations de 1940. Terra Nostra, Revista Escolar Catalana, 42: 206.

8. Rogers R., Marks F., Marchok T., 2009. Tropical cyclone rainfall. In: (Ed.), M.G.A. (Ed.), Encyclopedia of hydrological sciences, Chichester, UK:John Wiley \& Sons, Ltd. DOI:10.1002/0470848944.hsa030 
9. Boissier L. (2013). La mortalité liée aux crues torrentielles dans le Sud de la France: une approche de la vulnérabilité humaine face à l'inondation. PhD, Univ. Montpellier III, $215 \mathrm{p}$.

10. Vinet F. (2008). Geographical analysis of damage due to flash floods in southern France: The cases of 12-13 November 1999 and 8-9 September 2002. Applied Geography, 28(4): 323-336.

11. Chauvière J.Y., Lafitte J.J., Le Quentrec M., Ravard J.L., Truchot C., Verdeaux P. (2010). Prévisions des crues et hydrométrie : évaluation des réseaux et perspectives, $\mathrm{n}^{\circ} 005620-01$. Ministère de l'Ecologie, de l'Energie, du Développement durable et de la Mer, www.cgedd.developpement-durable.gouv.fr, $129 \mathrm{p}$.

12. Bertin X., Bruneau N., Breilh J.F., Fortunato A.B. and Karpytchev M. (2012). Importance of wave age and resonance in storm surges: the case Xynthia, Bay of Biscay. Ocean Modelling, 42, 16-30.

13. Jonkman S.N., Vrijling J.K. and Vrouwenvelder, A.C. (2008). Methods for the estimation of loss of life due to floods: A literature review and a proposal for a new method. Nat. hazards, 46 (3), 353-389.

14. Di Mauro M., De Bruijn K.M., Meloni M. (2012). Quantitative methods for estimating flood fatalities: Towards the introduction of loss-of-life estimation in the assessment of flood risk. Nat. hazards, 63, 1083-1113.

15. Vinet F., Lumbroso D., Defossez S. and Boissier, L. (2012). A comparative analysis of the loss of life during two recent floods in France: The sea surge caused by the storm Xynthia and the flash flood in Var. Nat. Hazards, 61 (3), 1179-1201.

16. Ribes J. (1982) Tome 3 : Séisme et inondations, le cataclysme de 1940, In: Castillet ED, Haut et moyen Vallespir au fil du temps, Perpignan, $190 \mathrm{p}$.

17. Wilson T. (2006) Les risques de blessures et de décès par imprudence lors des inondations. Responsabilité et environnement, 43, 57-63

18. Lumbroso D.M., Sakamoto D., Johnstone W.M., Tagg, A.F. and Lence B. (2011). The development of a Life Safety Model to estimate the risk posed to people by dam failures and floods, Dams and Reservoirs Journal of the British Dam Society, 21(1), 31-43.

19. Boudou M., Danière B., Lang M. (2016). Assessing changes in urban flood vulnerability through mapping land use from historical information. HESS, 20, 161-173, doi:10.5194/hess-20-161-2016.

20. Anziani A. (2010). Rapport d'information fait au nom de la mission commune d'information sur les conséquences de la tempête Xynthia. Sénat, rapport d'information $\mathrm{n}^{\circ} 647,7$ juillet 2010, 227 p. 